\title{
4-Methylthioamphetamine (4-MTA) induces mitochondrial-dependent apoptosis in SH-SY5Y cells independently of dopamine and noradrenaline transporters
}

Therese Montgomery ${ }^{1 *}$, Harald Sitte ${ }^{1}$, Gethin McBean ${ }^{2}$

From 16th Scientific Symposium of the Austrian Pharmacological Society (APHAR)

Vienna, Austria. 25-27 November 2010

\section{Background}

3,4-Methylenedioxymethamphetamine (MDMA or 'ecstasy') tablets are frequently contaminated by 4-MTA ('flatliner'), an amphetamine derivative which is known to induce severe human intoxication and even death. Although an equipotent inducer of SERT-dependent 5-HT release in vivo, 4-MTA does not induce MDMAlike serotoninergic neurotoxicity in rats. Instead, 4-MTA users typically report unpleasant sympathomimetic effects such as tachycardia, tremors, stomach cramps, headache and sweating following ingestion. Here, for the first time we investigate the cytotoxic potency of 4-MTA in a catecholaminergic system.

\section{Methods}

SH-SY5Y cells express both dopamine and noradrenaline transporters (DAT, NET) in the presence of vesicular monoamine transporter 2 (VMAT2) and were therefore chosen as the ideal catecholaminergic model in which to examine the molecular mechanisms of 4-MTA and MDMA-induced cytotoxicity in vitro. Cell viability was determined using the MTT assay and validated using flow cytometry via PI exclusion. ROS production, mitochondrial membrane potential (MMP), apoptosis and the cell cycle were examined via flow cytometry using $\mathrm{DCFH}_{2} \mathrm{DA}, \mathrm{JC}-1$, annexin V/PI and PI respectively. The level of intracellular calcium was determined ratiometrically by confocal microscopy using two

\footnotetext{
* Correspondence: therese.montgomery@ucd.ie

${ }^{1}$ Institute of Pharmacology, Center of Physiology and Pharmacology, Medical University of Vienna, 1090 Vienna, Austria

Full list of author information is available at the end of the article
}

visible wavelength $\mathrm{Ca}^{2+}$-sensitive dyes, Fluo-3 and Fura Red.

\section{Results}

4-MTA was significantly more cytotoxic than MDMA at $24 \mathrm{~h}$, demonstrating an $\mathrm{EC}_{50}$ of $0.60 \mathrm{mM}$ in contrast to $2.01 \mathrm{mM}$ for MDMA. In addition, the combination of MDMA and 4-MTA at low concentrations significantly increased cytotoxicity compared to that of each drug alone. 4-MTA-induced cell death was reduced by the anti-oxidant $N$-acetyl-L-cysteine (NAC) but not by the non-selective monoamine transport inhibitor indatraline, indicating that monoamine transport is not a requirement of 4-MTA-induced cytotoxicity. Drug-induced cell death was pre-empted by rapid intracellular $\mathrm{Ca}^{2+}$ influx, mitochondrial membrane depolarization (MMD), ROS production and caspase 9 activation. MDMA and 4-MTA also induced phosphatidlyserine exposure and caspase-dependent DNA fragmentation at $24 \mathrm{~h}$ indicative of cell death via apoptosis.

\section{Conclusions}

Although both MDMA and 4-MTA induced apoptosis via the mitochondrial death pathway, 4-MTA does so at more physiologically relevant concentrations and may therefore be a potent synergistic adjunct when mixed with MDMA.

\section{Acknowledgements}

This work was supported by the Health Research Board (HRB), Ireland. 


\section{Author details}

IInstitute of Pharmacology, Center of Physiology and Pharmacology, Medical University of Vienna, 1090 Vienna, Austria. ${ }^{2}$ Conway Institute of Biomolecular and Biomedical Research, University College Dublin, Dublin 4, Ireland.

Published: 16 November 2010

doi:10.1186/1471-2210-10-S1-A22

Cite this article as: Montgomery et al:: 4-Methylthioamphetamine

(4-MTA) induces mitochondrial-dependent apoptosis in SH-SY5Y cells independently of dopamine and noradrenaline transporters. BMC

Pharmacology 2010 10(Suppl 1):A22.

Submit your next manuscript to BioMed Central and take full advantage of:

- Convenient online submission

- Thorough peer review

- No space constraints or color figure charges

- Immediate publication on acceptance

- Inclusion in PubMed, CAS, Scopus and Google Scholar

- Research which is freely available for redistribution

Submit your manuscript at www.biomedcentral.com/submit

() Biomed Central 